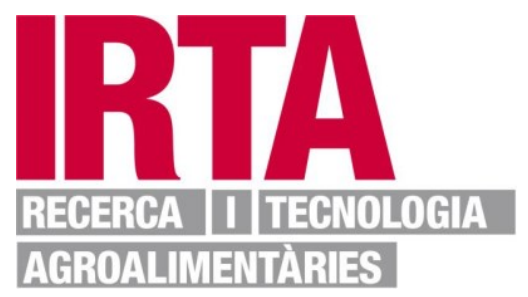

This document is a postprint version of an article published in Food Science and Technology International after peer review. To access the final edited and published work see https://doi.org/10.1177/10820132211022112

Information for Users of the Institutional Repository

Users who receive access to an article through a repository are reminded that the article is protected by copyright. Users may download and save a local copy of an article accessed in an institutional repository for the user's personal reference. For permission to reuse an article, please follow our Process for Requesting Permission

Document downloaded from: 


\title{
Innovative strategies to enhance the sensory quality of dry fermented sausages containing lactic ingredients by the addition of exogenous enzymes
}

Short title: Enzyme addition to enhance dry fermented sausages sensory quality Katharina Stollewerk ${ }^{1,2}$, Anna Jofré ${ }^{2 *}$, Josep Comaposada ${ }^{1}$, M. Dolors Guardia ${ }^{1}$, Jacint Arnau ${ }^{1}$, Kieran Kilcawley ${ }^{3}$

${ }^{1}$ IRTA. Food Technology Programme. Finca Camps i Armet. E-17121 Monells (Girona), Spain. ${ }^{2}$ IRTA. Food Safety Programme. Finca Camps i Armet. E-17121 Monells (Girona), Spain.

${ }^{3}$ Teagasc Food Research Centre, Moorepark, Fermoy, Co. Cork, Ireland.

*Corresponding author. Tel.: +34 972630052. E-mail address: anna.jofre@ irta.cat (A. Jofré)

\begin{abstract}
This study investigated the impact of the addition of exogenous enzymes (Accelerzyme CPG, Debitrase DBP20) or cellular preparations (FlavoGard), traditionally used in the cheese industry, to accelerate flavour development of dry fermented sausages with $6 \%$ of lactic derivatives content. Sausages were fermented to $\mathrm{pH}$ 5.0, dried for 32 days and vacuum packed stored under refrigeration for 60 days. Sausages were analysed for physicochemical parameters, technological microbiota and proteolysis after fermentation, drying/ripening and storage. Similar compositional results were obtained in all products (38-39\% humidity in the final product; $38.2 \%$ fat and 40.7 $\%$ protein as dry matter throughout the study). Debitrase application positively affected proteolysis by changing the free amino acid profile and increasing Non-protein nitrogen and total free amino acids by 2.2 and 11.8-fold, respectively. Accelerzyme increased ripened cheese flavour and overall sensory quality from 5.1 to 5.8; Debitrase increased ripened cheese odour and flavour, bitterness, umami, adhesiveness, pastiness, and overall sensory quality from 5.0 to 5.9, and decreased acid and hardness. This study highlights the benefits/effects of adding some exogenous enzyme/bacterial preparations traditionally used in the cheese industry to enhance the flavour of dry fermented sausages containing high content of lactic ingredients and increase its sensory quality.
\end{abstract}

\section{KEYWORDS}

Cellular preparations; Flavour development; Proteolysis; Ripening; Salchichón 


\section{INTRODUCTION}

Dry fermented sausages play an important part in many diets, providing valuable protein and fat nutrients with appealing flavours. The flavour of dry fermented sausages is the result of a complex combination of taste compounds. Most of these substances are formed by enzymatic reactions or chemical processes that take place during ripening (Zhao, Schieber \& Gänzle, 2016). Proteolysis is one of the main mechanisms, together with lipolysis, for the formation of flavour compounds in dry-fermented sausages. During their production process and due to the activity of endogenous and microbial enzymes, meat proteins are hydrolysed to polypeptides that can be further degraded to large amounts of smaller peptides and free amino acids (Gallego, Mora, Escudero \& Toldrà 2018). Studies investigating the biochemical properties of dry fermented sausages revealed that the ingredients, manufacturing conditions, starter cultures, spices and diameter are the primary determinants of the proteolysis pattern and the characteristic flavour properties associated with each sausage type and/or brand (Puolane \& Petäjä-Kanninen, 2015; Montanari et al., 2018; Gallego et al. 2018).

However, actual trends for meat products, e.g. the reduction of fat and salt contents (European Commission, 2009) and manufacturer's objectives to reduce production costs (Arnau, Serra, Comaposada, Gou, \& Garriga, 2007), have an impact on product sensory characteristics. Therefore, innovative strategies able to diversify and improve the odour and flavour of dry fermented sausages are necessary. Among those strategies, the addition of different bacterial starter cultures or yeast strains have been evaluated (Flores, Corral, Cano-García, Salvador, \& Belloch, 2015; Aro Aro et al. 2010; Lorenzo, Fonseca, Gómez \& Domínguez, 2016).

Additionally, as fermentation is an integral feature of both dry sausage and cheese production, this had led to the evaluation of commercial enzymes or bacterial preparations to diversify the range of flavour in fermented meat and milk products (Arnau, Serra, Comaposada, Gou \& Garriga, 2007). Exogenous proteases and lipases have been used to accelerate the ripening of dry fermented sausages, with the primary aim of reducing production costs. However, up to date a 
significant improvement in flavour development has been detected only in a minority of studies (Fernández, Ordóñez, Bruna, Herranz, \& de la Hoz, 2000; Leroy, Geyzen, Janssens, De Vuyst \& Scholliers, 2013).

In previous studies on cheese, the commercial preparations Accelerzyme $\mathrm{CPG}^{\circledR}$, Debitrase DBP 20 and FlavoGard ${ }^{\circledR}$ were shown to be appropriate for cheese flavour development, while acting in different ways on protein breakdown (Kilcawley, Nongonierma, Hannon, Doolan, \& Wilkinson, 2012; Kilcawley, Wilkinson, \& Fox, 2006). To the best of our knowledge, none of these products had been tested yet in dry fermented sausages with a high lactic derivatives content, which is a common composition in some Spanish fermented sausages (Gou et al., 1998) that increases sweetness, protein content and dry matter and provides a slight lactic nuances. Therefore, and given the consumer demands for safe products of quality and the technological and economical interest of the fermented sausages manufacturers in accelerating the ripening process (Fernández et al., 2000, Leroy et al., 2013), the objective of this study was to evaluate the suitability of the application of Accelerzyme CPG $^{\circledR}$, Debitrase DBP 20 and FlavoGard ${ }^{\circledR}$ commercial preparations in salchichón type dry fermented sausages containing a $6 \%$ of powder lactic derivative ingredients (i.e. milk powder, lactose and casein) by evaluating its impact on the microbiology, physicochemical characteristics, proteolysis and sensory properties.

\section{MATERIALS AND METHODS}

\section{Sausage manufacturing and enzyme application}

Two independent trials were performed on different days, in which 7 batches were produced. For each batch $(15 \mathrm{~kg})$, the following ingredients were mixed: $824 \mathrm{~g} / \mathrm{kg}$ of pork shoulder meat $(65 \%)$, lean pork meat (19\%) and pork fat (17\%), $60 \mathrm{~g} / \mathrm{kg}$ soy mash (Solae LLC, St. Louis, Missouri), 25 g/kg milk powder, $25 \mathrm{~g} / \mathrm{kg}$ lactose (Firesland Foods Domo USA Inc., Chicago) and $5 \mathrm{~g} / \mathrm{kg}$ dextrose (Cargill, Martorell, Barcelona, Spain), $25 \mathrm{~g} / \mathrm{kg} \mathrm{NaCl}, 15 \mathrm{~g} / \mathrm{kg}$ decalcified water, $10 \mathrm{~g} / \mathrm{kg}$ casein (DMV International, The Netherlands), $2.5 \mathrm{~g} / \mathrm{kg}$ black pepper, $0.5 \mathrm{~g} / \mathrm{kg}$ erythrobate, 0.15 
$\mathrm{g} / \mathrm{kg}$ potassium nitrate, $0.15 \mathrm{~g} / \mathrm{kg}$ sodium nitrite and $0.05 \mathrm{~g} / \mathrm{kg}$ carmine. Meat and fat were previously ground through a $5 \mathrm{~mm}$ plate (model PM 114, Castellvall S.A. Riudellots de la Selva, Spain) and the soy mash was prepared by mixing $800 \mathrm{~g} / \mathrm{kg}$ water, $200 \mathrm{~g} / \mathrm{kg}$ soy protein, $20 \mathrm{~g} / \mathrm{kg}$ salt and $0.05 \mathrm{~g} / \mathrm{kg}$ of carmine in a bowl chopper until it showed a homogenous bright appearance. To every batch, lyophilised starter cultures Pediococcus pentosaceus and Staphylococcus xylosus (0.25 g/kg, Lyocarni RHM-33, Sacco, Italy) were added. The enzyme/cellular preparations Accelerzyme $\mathrm{CPG} \AA$, a carboxypeptidase purified from Aspergillus niger (DSM Food Specialities, Delft, The Netherlands), Debitrase ${ }^{\mathrm{TM}}$ DBP20, a mixture of purified enzymes from Lactococcus lactis and Aspergillus oryzae (DuPont, Dange St Romain, France) and FlavoGard®, a flavour adjunct culture from L. lactis subspecies cremoris (DuPont, France) were initially dissolved in $500 \mathrm{ml}$ of sterile water and then applied separately at a low and a high dose rate. The dose rates were chosen based on supplier recommendations and on published data (Kilcawley, Wilkinson, \& Fox, 2002a; Zapelena, Ansorena, Zalacain, Astiasarán, \& Bello, 1998). Each trial contained a Control without addition of enzyme preparation. The following batches were produced: Control, CPG-Lo, CPG-Hi, DBP-Lo, DBP-Hi, FL-Lo and FL-Hi, details of the trials and doses are provided in Figure 1. The meat batter was mixed for 3 min before and 1 min after the addition of the enzyme/cellular preparations at $0^{\circ} \mathrm{C}$ in an AVT-150 mixer under vacuum conditions (Castellvall S.A., Castellar del Vallès, Spain) to achieve a homogenous distribution and subsequently stuffed in 50-60 mm diameter collagen casings (Fibran, Fibran S.A., Sant Joan de les Abadesses, Spain) in pieces of $1 \mathrm{~kg}$ (time $0(\mathrm{t} 0)$ samples). Sausages were then fermented for $24-48 \mathrm{~h}$ at $22-23{ }^{\circ} \mathrm{C}$ at a relative humidity $(\mathrm{RH})$ of $90-95 \%$ until the $\mathrm{pH}$ decreased to $5.0(\mathrm{t} 1)$. The sausages were then dried for ca. 32 days at $14-16{ }^{\circ} \mathrm{C}(\mathrm{RH} 75-80 \%)$ until a weight loss of $\sim 30 \%$ was achieved ( $\mathrm{t} 2$ ). At the end of the drying process, sausages were vacuum-packed to avoid further reduction of weight loss and stored under refrigeration $\left(5^{\circ} \mathrm{C}\right)$ for 60 days (t3). Different randomly selected sausages were used at each sampling time and all the analyses were performed in duplicate.

[insert Figure 1] 


\section{Microbiological analysis}

For each sampling time (t0,t1,t2 and $\mathrm{t} 3), 25 \mathrm{~g}$ of sausage samples were aseptically minced, 1:10 diluted in $0.1 \%$ Bacto Peptone (Difco Laboratories, Detroit, MI, USA) with $0.85 \% \mathrm{NaCl}$ and homogenized for $1 \mathrm{~min}$ in a Masticator Classic (IUL S.A., Barcelona, Spain). After doing the appropriate dilutions (in $0.1 \%$ Bacto Peptone with $0.85 \% \mathrm{NaCl}$ ), lactic acid bacteria (LAB), gram positive catalase positive cocci (GCC+) and Lactococcus lactis (FlavoGard batches) were determined by plating on De Man Rogosa and Sharpe agar (MRS, Merck, Darmstadt, Germany), Mannitol Salt Phenol-red agar (MSA, Merck) and LM17-agar (AES Chemunex, Barcelona, Spain), respectively, after incubation of $48-72 \mathrm{~h}$ at $30^{\circ} \mathrm{C}$. Yeasts and moulds were counted in Yeast-Glucose-Chloramphenicol agar (YGC, Merck) incubated for 5 days at $25^{\circ} \mathrm{C}$.

\section{Physicochemical and compositional analysis}

The $\mathrm{pH}$ was determined with a portable $\mathrm{pH}-$ meter (Crison $\mathrm{pH} 25$. Crison 133 Instruments S.A., Alella, Spain). Water activity $\left(\mathrm{a}_{\mathrm{w}}\right)$ was measured at $25{ }^{\circ} \mathrm{C}$ using an S3TE Aqualab equipment (Decagon Devices, Inc. Pullman, Washington, USA). The fat, protein and moisture contents were determined according to the AOAC official method 2007.04 (Anderson, 2007) with a FoodScan ${ }^{\mathrm{TM}}$ device (FOSS Analytic, Hillerod, Denmark), which uses the near-infrared spectrophotometer system.

\section{Proteolysis analysis}

For proteolytic analysis, $10 \mathrm{~g}$ of ground sample was homogenized with $20 \mathrm{ml}$ of $2 \%$ trichloroacetic acid (TCA) (Hughes et al,. 2002) using an Ultra-Turrax (IKA T18 basic) and then centrifuged at $27000 \times g$ for $20 \mathrm{~min}$ at $4{ }^{\circ} \mathrm{C}$. The supernatant was filtered (Whatman No1, Whatman International Ltd. Maidstone, England) and the obtained 2\% TCA-soluble extract was used for the determination of non-protein nitrogen content (NPN) by Kjeldahl and quantification of individual free amino acids (FAA) by HPLC. For individual FAA analysis, the most relevant amino acids were analysed. Samples were deproteinised by mixing equal volumes of $24 \%$ (w/v) 
TCA, these were allowed to stand for $10 \mathrm{~min}$ before centrifuging at $14400 \times g$ (Microcentaur, MSE, UK) for $10 \mathrm{~min}$. Supernatants were removed and diluted with $0.2 \mathrm{M}$ sodium citrate buffer, at $\mathrm{pH} 2.2$ to give approx. $250 \mathrm{nmol}$ of each amino acid residue. Samples were then diluted 1:2 with the internal standard norleucine, to give a final concentration of $125 \mathrm{nmol} / \mathrm{ml}$. Amino acids were quantified using a Jeol JLC-500/ V amino acid analyser (Jeol Ltd., Garden city, Herts, UK) fitted with a Jeol $\mathrm{Na}^{+}$high performance cation exchange column. Results were expressed in $\mathrm{mg} / 100 \mathrm{~g}$ of dry matter.

\section{Sensory analysis: Quantitative Descriptive Analysis (QDA)}

A Quantitative Descriptive Analysis (QDA) was applied to provide quantitative description of products based on the perceptions of a group of trained assessors (Stone, Sidel, Oliver, Woolsey \& Singleton, 1974; Stone and Sidel, 1993). Six selected and trained assessors (ASTM, 1981; ISO 8586-1, 1993 and ISO 8586-2, 1994) with a minimum of ten years of experience in tasting meat products undertook the sensory analysis on $1 \mathrm{~mm}$-thick slices of dry fermented sausages at the end of the storage period. The generation of the descriptors was carried out by open discussion in two previous sessions. The descriptors retained were: acid odour (intensity of a sharp acid odour), ripened cheese odour (intensity of odour characteristic of cheese ripened for a long period of time), cooked odour (intensity of odour sensation elicited by pork fat cooked in water at $100{ }^{\circ} \mathrm{C}$ and refrigerated at $3 \pm 2{ }^{\circ} \mathrm{C}$ (Ferrini et al,. 2012)), acid flavour (basic taste sensation elicited by an acid), bitterness (basic taste sensation elicited by L-Tryptophan), saltiness (basic taste sensation elicited by $\mathrm{NaCl}$ ), umami (basic taste sensation elicited by sodium glutamate), ripened cheese flavour (flavour characteristic of cheese ripened for a long period of time), adhesiveness (textural property rated by the degree to which the surface of the dry fermented sausage slice adheres to the palate when compressed with the tongue), hardness (force required to bite through the sample), crumbliness (textural property characterised by easiness with which a sample can be separated into smaller particles during chewing), and pastiness (feeling of paste detected in hams with a high proteolytic index). Overall sensory quality (scoring of the sensory quality of the 
sample by reference to the standard of quality for a product) was also assessed. A non-structured scoring scale was used, where 0 meant absence of the descriptor and 10 meant high intensity of the descriptor. Sensory evaluation was undertaken separately in three sessions/sampling time and a complete block design was used, where each taster assessed all the treatments in each session. A total of 9 sensory sessions were carried out. Samples were coded with three random numbers and were presented to the assessors balancing the first order and the carry over effects (MacFie, Bratchell, Greenhoff \& Vallis, 1989). The average score of the six experts for each sample and session was recorded and used in the statistical analysis.

\section{Data analysis}

Analysis of variance (ANOVA) and the post-hoc Tukey test at a $p<0.05$ significance level were carried out using Statistica 7.0 software (Statsoft, Tulsa, UK). For determining statistical differences among batches in composition, physicochemical parameters, technological microbiota, NPN and Total FAA, the model included the batch and the sampling time as fixed factors. Analysis of individual FAA was carried out at each sampling time and, as a consequence, the model included as main factor the batch.

Data from quantitative descriptive sensory analysis was evaluated using SAS for Windows version 9.1 (SAS, 2005). For the sensory attributes, the average scores of the panel for each fermented sausage from 2 replicates and 2 sampling points ( 2 and $t 3$ ) was used. The model included treatment, replicate and sensory session as fixed effects. In all cases, the interaction between fixed effects was tested and dropped from the model since it was not significant.

\section{RESULTS AND DISCUSSION}

\section{Microbiota, physicochemical parameters and composition}

The technological microbiota, $\mathrm{pH}, \mathrm{a}_{\mathrm{w}}$, and composition (moisture, protein and fat contents) were not significantly affected by the addition of the enzyme preparations ( $p>0.05$ ) (Figure 2 and 3). 
Yeasts and moulds kept $c a .3 \mathrm{log}$ cfu/g throughout the study. Initial LAB and GCC+ counts correspond to the added starter culture levels (both $c a .6 .6 \log \mathrm{cfu} / \mathrm{g}$ ). LAB increased $2.5 \operatorname{logs}$ during fermentation and maintained at ca. $9 \mathrm{log}$ cfu/g during the rest of the study. GCC+, described as less competitive than LAB (Stollewerk, Jofré, Comaposada, Ferrini \& Garrriga, 2011), remained at initial levels until the end of ripening and slightly decreased (1.7 logs) during the 2 months of refrigerated storage. $\mathrm{pH}$ decreased from 5.6 to 5.0 during fermentation and ripening and was 5.1 in the final product. As expected in dry fermented sausages (Corral, Salvador \& Flores, 2013), progressive dehydration decreased $\mathrm{a}_{\mathrm{w}}$ and water content at the end of ripening and drying to 0.906 and $38.53 \%$, respectively. Consequently, the fat and protein contents increased to 23.46 and $25.62 \%$, respectively, at the end of drying and remained at the same levels during subsequent refrigerated storage due to vacuum-package and refrigeration storage (38.2 \pm $0.1 \%$ of fat and $40.7 \pm 1.2 \%$ of protein as dry matter). Levels of fat and protein are in the range of salchichón type sausages although they are highly dependent on the manufacturer/brand (Beriain, Chasco \& Lizaso, 2000).

[insert Figure 2 and Figure 3]

\section{Proteolysis analysis}

Intensity of proteolysis, assessed by nonprotein nitrogen content (NPN) is shown in Table 1. After fermentation (t1), values significantly increased in all the batches although the highest increase was observed in DBP-Lo and DBP-Hi. Subsequently, they remained at similar levels ( $\mathrm{p}>0.05, c a$. $10-11 \%)$ in all the batches except for DBP-Lo and DBP-Hi ( $\mathrm{p}<0.05)$, which increased up to 13.3 and $17.0 \%$ (1.7 and 2.2 fold increase compared to the meat batter (t0), respectively, at the end of storage. The same trend was observed by total FAA, with increases from t0 to $\mathrm{t} 3$ ranging from 5 fold (in Control and CPG-Lo) to 12-fold (in DBP-Hi).

During the whole experiment, levels of individual free amino acids, increased, especially during the drying/ripening 32-day period (t2, Figure 4). Only levels of ARG decreased in all batches 
from t0 to $\mathrm{t} 1$ and remained at low levels $(<4 \mathrm{mg} / 100 \mathrm{~g})$ during the rest of the study. ARG has been described to be metabolized by several species of LAB, which use the amino acid for survival and convert it to flavour compounds (Chen, Liu, Sun, Kong, \& Xiong, 2015; Gallego et al. 2018). Regarding the Control batch, the predominant amino acids in the dry product were HIS $(99,47$ mg/100 g), GLU (86,70 mg/100g), LEU (40,42 mg/100g), ALA (39,40 mg/100g), LYS $(34,55$ $\mathrm{mg} / 100 \mathrm{~g})$, THR $(30,35 \mathrm{mg} / 100 \mathrm{~g})$, VAL $(28,99 \mathrm{mg} / 100 \mathrm{~g})$ and PHE $(26,81 \mathrm{mg} / 100 \mathrm{~g})$, showing concentrations higher than $20 \mathrm{mg} / 100 \mathrm{~g}$. The high levels of Glu agree with results obtained for other fermented sausages with a fermentation step at $20-27^{\circ} \mathrm{C}$, which independently of the formulation showed a higher production of GLU than fermented sausages produced at low temperatures (Gallego et al., 2018, Aro Aro et al., 2010). In this regard, differences in the profiles of different fermented sausages have been related with the applied starter culture/s and the processing conditions (i.e. time and temperature of fermentation and drying), that determine the activity of enzymes of muscular and bacterial origin (Dominguez et al., 2016, Gallego et al., 2018). In contrast to the present results, low levels of HIS were detected in the mentioned studies. Conversely, Henriksen \& Stahnke (1997) found high levels of HIS in Danish salami and related this fact to the presence of histidine dipeptides in skeletal muscle, the concentration depending on muscle type and possibly to the proportion of beef meat in the salami. 
Table 1. Changes in non-protein nitrogen (NPN) and total free amino acids (FAA) throughout manufacturing and storage of dry fermented sausages.

\begin{tabular}{|c|c|c|c|c|c|}
\hline Batch & to & $\mathrm{t} 1$ & t2 & t3 & $\begin{array}{l}\text { Fold } \\
\text { increase }\end{array}$ \\
\hline \multicolumn{6}{|c|}{ Non-Protein Nitrogen (NPN), in \% of total $\mathrm{N}$} \\
\hline Control & $7.9 \pm 0.6$ & $7.5 \pm 0.4^{d}$ & $9.6 \pm 0.6^{c}$ & $10.4 \pm 1.0^{b c}$ & 1.3 \\
\hline CPG-LO & - & $8.9 \pm 0.4^{c}$ & $10.2 \pm 0.7^{c}$ & $9.2 \pm 1.1^{\mathrm{c}}$ & 1.2 \\
\hline CPG-Hi & - & $9.0 \pm 0.3^{c}$ & $10.4 \pm 0.7^{c}$ & $10.6 \pm 0.3^{c}$ & 1.3 \\
\hline DBP-Lo & - & $11.6 \pm 0.1^{\mathrm{b}}$ & $14.8 \pm 0.5^{b}$ & $13.3 \pm 1.7^{b}$ & 1.7 \\
\hline DBP-Hi & - & $12.7 \pm 0.3^{a}$ & $16.2 \pm 0.1^{\mathrm{a}}$ & $17.0 \pm 0.2^{\mathrm{a}}$ & 2.2 \\
\hline FL-Lo & - & $9.1 \pm 0.0^{c}$ & $10.1 \pm 0.3^{c}$ & $11.2 \pm 1.1^{\mathrm{bc}}$ & 1.4 \\
\hline $\mathrm{FL}-\mathrm{Hi}$ & - & $9.4 \pm 0.4^{c}$ & $10.7 \pm 0.3^{c}$ & $10.1 \pm 1.9^{c}$ & 1.3 \\
\hline \multicolumn{6}{|c|}{ Total Free Amino Acids (FAA), in $\mathrm{mg} / 100 \mathrm{~g}$ dry matter } \\
\hline Control & $92.1 \pm 0.3$ & $97.2 \pm 0.4^{\mathrm{e}}$ & $380.0 \pm 7.5^{c}$ & $487.9 \pm 3.3^{\mathrm{cd}}$ & 5.3 \\
\hline CPG-Lo & - & $129.4 \pm 12.2^{d}$ & $414.7 \pm 68.6^{c}$ & $446.2 \pm 30.5^{d}$ & 4.8 \\
\hline CPG-Hi & - & $133.0 \pm 3.6^{d}$ & $404.7 \pm 22.9^{c}$ & $519.3 \pm 23.9^{\mathrm{cd}}$ & 5.6 \\
\hline DBP-Lo & - & $184.0 \pm 12.5^{b}$ & $740.9 \pm 38.0^{b}$ & $814.7 \pm 85.7^{b}$ & 8.8 \\
\hline DBP-Hi & - & $226.9 \pm 3.9^{a}$ & $903.6 \pm 16.7^{\mathrm{a}}$ & $1089.1 \pm 16.0^{\mathrm{a}}$ & 11.8 \\
\hline FL-Lo & - & $162.6 \pm 4.3^{c}$ & $474.9 \pm 9.7^{c}$ & $621.4 \pm 63.4^{\mathrm{c}}$ & 6.7 \\
\hline $\mathrm{FL}-\mathrm{Hi}$ & - & $173.3 \pm 10.5^{b c}$ & $492.3 \pm 58.5^{c}$ & $588.7 \pm 104.7^{c d}$ & 6.4 \\
\hline
\end{tabular}

Data represent mean values of 2 independent experiments performed in duplicate \pm standard deviation.

Small letters in a column indicate significant differences $(\mathrm{p}<0.05)$ between batches.

-: not determined

${ }^{1}$ Fold increase throughout the process, i.e., from the meat batter to the end of storage 
Nevertheless, LEU, PHE, VAL, LYS, GLU and ALA, some of the FAA detected in the evaluated salchichón, were shown to be the most predominant in other meat products (foal sausage (Domínguez et al., 2016; Lorenzo \& Franco, 2012), foal "cecina" (Aro et al., 2010; Lorenzo, Fonseca, Gómez, \& Domínguez, 2015) and dry cured lacón (Garrido, Domínguez, Lorenzo, Franco, \& Carballo, 2012). Those FAA, specifically compounds originated by the degradation of VAL, LEU and ILE have been linked to the ripened flavour of fermented foods (Herranz 2006).

Taking into account the added enzymatic preparations, FAA levels changed in parallel with the dose rate, except for the FL batches, where greater levels ( $p>0.05)$ were found in FL-Lo than in FL-Hi samples at the end of storage (t3). The greatest increase over the Control was in DBP-Hi sausages, where significant differences were observed for all FAA at t1 (except PRO and ARG), t2 (except ARG) and t3 (2- to 3-fold amounts). Elevated levels of FAA (except for ARG) were also observed in the FL-Lo, FL-Hi and DBP-Lo batches over the Control at t1, t2 and $\mathrm{t} 3$ (Figure 4). For both CPG samples (CGP-Lo and CPG-Hi), in contrast, significantly higher levels than in the Control were observed for THR, GLY, ALA, VAL, MET, LEU, TYR and HIS at t1, but not at $\mathrm{t} 2$ and $\mathrm{t} 3$.

\section{[Insert Figure 4]}

These results can be explained by the fact that Debitrase DBP20 had the highest proteinase activity and therefore, DBP batches had the highest NPN and total FAA levels. It has been reported that products derived from Aspergillus spp have high levels of Pep N activity and products from L. lactis have highest levels of PepX activity (Kilcawley et al., 2002a). This explains why Debitrase ${ }^{\mathrm{TM}}$ DBP 20, containing L. lactis together with Aspergillus oryzae is the product with the highest effect on protein breakdown. Furthermore, Debitrase DBP20 was shown to have high levels of peptidase A, which generates GLU and to have significant levels of prolinespecific activities (Kilcawley et al., 2002a; Kilcawley, Wilkinson, \& Fox, 2002b). FlavoGard ${ }^{\circledR}$, a flavour adjunct culture of L. lactis subsp. cremoris described by its manufacturers to have high aminopeptidase activity and Accelerzyme $\mathrm{CPG}^{\circledR}$, a purified enzyme preparation containing a 
34 specific carboxypeptidase (Kilcawley et al., 2012), did not remarkably increase levels of NPN but

35 modified FAA total levels and profile. In this regard, the enzyme preparations used in the present

36 study increased the amount of aroma flavour formation precursors, anticipating a varying flavour

37 in fermented sausages. We observed high amounts of HIS and GLU. Sofrza et al. (2006) pointed

38 out that GLU and ASP helped umami taste in Parma ham. In addition, Zhao et al. (2005) observed

39 that LEU, ILE, ARG, HIS and PHE contributed to bitter taste in Jinhua ham.

\section{Sensory Analysis}

41 The sensory comparison of Control dry fermented sausages with those formulated with the enzyme preparations CPG, DBP and FL is shown in Table 2. The addition of CPG-Hi increased ripened cheese flavour and overall sensory quality compared to Control. No significant difference was found between control and FL batches. In contrast, the addition of DBP resulted in significant differences in some attributes. DBP-Hi samples scored higher ripened cheese odour and lower cooked odour. Ferrini et al. (2012) also observed a lower cooked flavour in fermented sausages with stronger flavour and antioxidant ingredients. In a similar way, the higher ripened cheese odour could mask the detection of cooked odour, which is considered as not appropriate for this kind of fermented sausages. 
Neither of these compounds were strongly associated with the DBP samples. Ripened cheese odour and flavour, bitter taste, umami, adhesiveness and pastiness were also higher $(\mathrm{p}<0.05)$ in the DBP-Hi samples than in the Control. In contrast, both acid taste and hardness were lower $(\mathrm{p}<0.05)$ in the DBP-Hi samples. All these results were in agreement with proteolysis results, which showed a higher increase of NPN and FAA levels during fermentation, ripening and specially at the end of storage in DBP sausages than in Control, CPG or FL. Ripened cheese odour and flavor was developed, in part, as in cheese, as a result of proteolysis and glycolysis of lactic ingredients, and to some extent to lipolysis of pork fat.

The overall sensory quality of sausages at the end of the storage was higher in sausages formulated with enzyme preparations CPG and DBP, but not in FL. In CPG batch, this score was higher in high dose batch. In DBP there was an increase in overall sensory quality between control and DBP-Lo, but no increase was observed between DBP-Lo and DBP-Hi probably because the improvement in some positive attributes (acid, umami, ripened cheese) was compensated by the increase in bitterness, pastiness, adhesiveness and decrease in hardness.

\section{CONCLUSIONS}

The application of the three evaluated enzyme preparations (i.e. Accelerzyme $\mathrm{CPG}$, FlavoGard ${ }^{\circledR}$ and Debitrase ${ }^{\mathrm{TM}}$ DBP20) developed for cheese on dry fermented sausages did not negatively affect physicochemical and microbial parameters. Conversely, sensory analysis revealed that flavour attributes were improved by CPG and DBP which could be suitable as flavour developers in dry fermented sausages with a high content of lactic ingredients.

\section{FUNDING}

This study was supported by the CDTI project CENIT Ref. 2007-2016 (Futural) from Spanish Ministry of Science and Innovation and by the CERCA Programme/Generalitat de Catalunya. K. S. received a predoctoral fellowship awarded by INIA. 


\section{DECLARATION OF CONFLICTING INTERESTS}

The Authors declare that there is no conflict of interest

87

\section{REFERENCES}

Anderson S. (2007). Determination of fat, moisture, and protein in meat and meat products by using the FOSS FoodScanTM Near Infrared Spectrophotometer with Foss artificial neural network calibration model and associated database: collaborative study. Journal of the AOAC International, 90(4), 1073-1083.

Arnau J., Serra X., Comaposada J., Gou P. \& Garriga M. (2007). Technologies to shorten the drying period of dry-cured meat products. Meat Science, 77(1), 81-89.

Aro Aro J. M., Nyam-Osor P., Tsuji K., Shimada K., Fukushima M \& Sekikawa M. (2010). The effect of starter cultures on proteolytic changes and amino acid content in fermented $\begin{array}{llll}\text { sausages. } & \text { Food } & \text { Chemistry, } & \text { 279-285. }\end{array}$ https://doi.org/10.1016/j.foodchem.2009.06.025

ASTM (American Society for Testing and Materials) (1981). Guidelines for the selection and training of sensory panel members. Special Technical Publication 758. Philadelphia (USA).

Beriain M. J., Chasco J., \& Lizaso G. (2000). Relationship between biochemical and sensory quality characteristics of different commercial brands of salchichon. Food Control, 11(3), 231-237. doi: https://doi.org/10.1016/S0956-7135(99)00104-8

Chen Q., Liu, Q., Sun Q., Kong B., \& Xiong Y. (2015). Flavour formation from hydrolysis of pork sarcoplasmic protein extract by a unique LAB culture isolated from Harbin dry sausage. Meat Science, 100, 110-117. doi: https://doi.org/10.1016/j.meatsci.2014.10.001 
Corral, S., Salvador, A., \& Flores, M. (2013). Salt reduction in slow fermented sausages affects the generation of aroma active compounds. Meat Science, 93 (3), 776-785. https://doi.org/10.1016/j.meatsci.2012.11.040

Domínguez R., Munekata P. E., Agregán R., \& Lorenzo J. M. (2016). Effect of commercial starter cultures on free amino acid, biogenic amine and free fatty acid contents in dry-cured foal sausage. LWT - Food Science and Technology, 71, 47-53. doi: https://doi.org/10.1016/j.lwt.2016.03.016

Escudero E., Aristoy M.C., Nishimura H., Arihara K., \& Toldrá F. (2012). Antihypertensive

effect and antioxidant activity of peptide fractions extracted from Spanish dry-cured ham. Meat science, 91(3), 306-311.

$\begin{array}{llll}\text { European } & \text { Commission. } & \text { (2009). } & \text { Salt }\end{array}$ http://ec.europa.eu/health/archive/ph_determinants/life_style/nutrition/documents/national_ salt_en.pdf.

Fernández M., Ordóñez J. A., Bruna J. M., Herranz B., \& de la Hoz L. (2000). Accelerated ripening of dry fermented sausages. Trends in Food Science \& Technology, 11(6), 201-209.

Ferrini G., Comaposada J., Arnau J., \& Gou P. (2012). Colour Modification in a Cured Meat Model Dried by Quick-Dry-Slice Process ${ }^{\circledR}$ and High Pressure Processed as a Function of $\mathrm{NaCl}, \mathrm{KCl}, \mathrm{K}$-lactate and Water Contents. Innovative Food Science \& Emerging Technologies, 13, 69-74. http://dx.doi.org/10.1016/j.ifset.2011.09.005

Flores M., Corral S., Cano-García L., Salvador A., \& Belloch C. (2015). Yeast strains as potential aroma enhancers in dry fermented sausages. International Journal of Food Microbiology, 212, 16-24. doi: https://doi.org/10.1016/j.ijfoodmicro.2015.02.028

Gallego, M., Mora, L., Escudero, E., \& Toldrá, F. (2018). Bioactive peptides and free amino acids profiles in different types of European dry-fermented sausages. International Journal of Food Microbiology, 276, 71-78. https://doi.org/10.1016/j.ijfoodmicro.2018.04.009

Garrido R., Domínguez R., Lorenzo J. M., Franco I., \& Carballo J. (2012). Effect of the length of salting time on the proteolytic changes in dry-cured lacón during ripening and on the sensory 
characteristics of the final product. Food Control, 25(2), 789-796. doi: https://doi.org/10.1016/j.foodcont.2011.11.036

Gou P., Garriga M., Guerrero L., Valero A., Andorrà J., Cubiñà I. \& Arnau J. (1998). Effect of sodium lactate and potassium bisulphite in a non-acid dry-cured sausage of reduced size. Fleischwirtschaft 78(4): 340-341.

Henriksen A. P., \& Stahnke L. H. (1997). Sensory and Chromatographic Evaluations of Water Soluble Fractions from Dried Sausages. Journal of Agricultural and Food Chemistry, 45, 2679-2684.

Herranz, B., Fernández, M., de la Hoz, L., \& Ordóñez, J. A. (2006). Use of bacterial extracts to enhance amino acid breakdown in dry fermented sausages. Meat Science, 72 (2), 318-325. https://doi.org/10.1016/j.meatsci.2005.08.002

Hughes M. C., Kerry J. P., Arendt E. K., Kenneally P. M., McSweeney P. L. H., \& O'Neill E. E. (2002). Characterization of proteolysis during the ripening of semi-dry fermented sausages. Meat Science, 62, 205-216.

ISO (International Organization for Standardization) 8586-1 (1993). Sensory Analysis — General Guidance for the Selection, Training and Monitoring of Assessors. Part 1: Selected Assessors. Geneva (Switzerland).

ISO (International Organization for Standardization) 8586-2 (1994). Sensory Analysis General Guidance for the Selection, Training and Monitoring of Assessors. Part 2: Experts. Geneva (Switzerland).

Kilcawley K. N., Nongonierma A. B., Hannon J. A., Doolan I. A., \& Wilkinson M. G. (2012). Evaluation of commercial enzyme systems to accelerate Cheddar cheese ripening. $\begin{array}{llll}\text { International } \quad \text { Dairy } & \text { Journal, } & \text { 26(1), } & \text { doi: }\end{array}$ http://dx.doi.org/10.1016/j.idairyj.2012.03.015

Kilcawley K. N., Wilkinson M. G., \& Fox P. F. (2002a). Determination of key enzyme activities in commercial peptidase and lipase preparations from microbial or animal sources. Enzyme 
and Microbial Technology, 31(3), 310-320. doi: http://dx.doi.org/10.1016/S01410229(02)00136-9

Kilcawley K. N., Wilkinson M. G., \& Fox P. F. (2002b). Properties of Commercial Microbial Proteinase Preparations. Food Biotechnology, 16(1), 29-55. doi: 10.1081/FBT-120004200

Kilcawley K. N., Wilkinson M. G., \& Fox P. F. (2006). A novel two-stage process for the production of enzyme-modified cheese. Food Research International, 39(5), 619-627. doi: http://dx.doi.org/10.1016/j.foodres.2005.12.006

Leroy, F., Geyzen, A., Janssens, M., De Vuyst, L., \& Scholliers, P. (2013). Meat fermentation at the crossroads of innovation and tradition: A historical outlook. Trends in Food Science \& Technology, 31 (2), 130-137. doi: https://doi.org/10.1016/j.tifs.2013.03.008

Lorenzo J. M., Fonseca S., Gómez M., \& Domínguez R. (2015). Influence of the salting time on physico-chemical parameters, lipolysis and proteolysis of dry-cured foal "cecina". $L W T$ Food Science and Technology, 60(1), 332-338. doi: https://doi.org/10.1016/j.1wt.2014.07.023

Lorenzo, J. M., Gómez, M., Purriños, L., \& Fonseca, S. (2016). Effect of commercial starter cultures on volatile compound profile and sensory characteristics of dry-cured foal sausage. Journal of the Science of Food and Agriculture, 96 (4), 1194-1201. doi: https://doi.org/10.1002/jsfa.7203

Lorenzo J. M., \& Franco D. (2012). Fat effect on physico-chemical, microbial and textural changes through the manufactured of dry-cured foal sausage Lipolysis, proteolysis and sensory properties. Meat Science, 92(4), 704-714. doi: https://doi.org/10.1016/j.meatsci.2012.06.026

MacFie, H.J., Bratchell, N., Greenhoff, K., Vallis, L.V., 1989. Designs to balance the effect of order of presentation and first-order carry-over effects in hall tests. J. Sensory Stud. 4, 129148. doi: https://doi.org/10.1111/j.1745-459X.1989.tb00463.x

Montanari C., Gatto V., Torriani S., Barbieri F., Bargossi E., Lanciotti R., Gardini, F. (2018). Effects of the diameter on physico-chemical, microbiological and volatile profile in dry 
fermented sausages produced with two different starter cultures. Food Bioscience, 22, 9-18. doi: https://doi.org/10.1016/j.fbio.2017.12.013

Puolane, E., \& Petäjä-Kanninen, E. (2015). Principles of Meat Fermentation. In Handbook of Fermented Meat and Poultry 2nd Ed. Editor-in-chief: Fidel Toldrà (pp. 13-17).

192

Sforza, S., Galaverna, G., Schivazappa, C., Marchelli, R., Dossena, A., \& Virgili, R. (2006). Effect of extended aging of Parma dry-cured ham on the content of oligopeptides and free amino acids. Journal of Agricultural and Food Chemistry, 54(25), 9422-9429. doi: https://doi.org/10.1021/jf061312+

Stollewerk, K., Jofré, A., Comaposada, J., Ferrini, G., \& Garriga, M. (2011). Ensuring food safety by an innovative fermented sausage manufacturing system. Food Control, 22 (12). https://doi.org/10.1016/j.foodcont.2011.05.016

Stone, H., Sidel, J., Oliver, S., Woolsey, A. and Singleton, R.C. (1974). Sensory evaluation by quantitative descriptive analysis. Food Technology, Vol. 28 No. 11, pp. 24-34. doi: https://doi.org/10.1002/9780470385036.ch1c

Stone, H. and Sidel, J.L. (1993). Sensory Evaluation Practices, Academic Press Inc., San Diego, CA.

Zapelena M. J., Ansorena D., Zalacain I., Astiasarán I., \& Bello J. (1998). Dry fermented sausages manufactured with different amounts of commercial proteinases: Evolution of total free $\alpha$ NH2-N groups and sensory evaluation of the texture. Meat Science, 49(2), 213-221. doi: http://dx.doi.org/10.1016/S0309-1740(97)00128-9

Zhao, C. J., Schieber, A., \& Gänzle, M. G. (2016). Formation of taste-active amino acids, amino acid derivatives and peptides in food fermentations - A review. Food Research International, 89, 39-47. doi: https://doi.org/10.1016/j.foodres.2016.08.042

Zhao, G. M., Zhou, G. H., Tian, W., Xu, X. L., Wang, Y. L., \& Luo, X. (2005). Changes of alanyl aminopeptidase activity and free amino acid contents in biceps femoris during processing of 
ham.

Meat

Science,

71(4),

612-619.

doi:

215 https://doi.org/10.1016/j.meatsci.2005.05.006 
217 Figure 1. Schematic representation of the production process of dry fermented sausages with and

218

219

220

221 without exogenous commercial enzymes or cellular preparations. The sampling time points are indicated as $\mathrm{t} 0=$ after mixing, $\mathrm{t} 1=\mathrm{after}$ fermentation, $\mathrm{t} 2=\mathrm{after}$ ripening/drying and $\mathrm{t} 3=$ after storage.

Figure 2. Development of $\mathrm{pH}$ and technological microbiota (Lactic Acid Bacteria (LAB) and Gram-Positive Catalase Positive cocci (GCC+)) in dry fermented sausages during fermentation (F), drying and refrigerated storage. Data represent mean values and standard deviation of all sausage batches.

Figure 3. Development of $\mathrm{a}_{\mathrm{w}}$ and compositional parameters humidity, protein content and fat content in dry fermented sausages during fermentation (F), drying and refrigerated storage. Data represent mean values and standard deviation of all sausage batches. Note that values expressed as dry matter were $38.2 \pm 0.1 \%$ for fat and $40.7 \pm 1.2 \%$ for protein throughout the study.

Figure 4. Changes in individual free amino acids (mg/ 100g dry matter) in dry fermented sausages in the meat batter ( $\mathrm{t} 0)$, after fermentation ( $\mathrm{t} 1)$, drying $(\mathrm{t} 2)$ and refrigerated storage $(\mathrm{t} 3)$. Data represent mean values and standard deviation of 2 independent experiments performed in duplicate. 